\title{
Voeding en fisieke welstand as deel van die skoolkurrikulum: 'n Intervensie in 'n onderwysopleidingprogram
}

\begin{tabular}{|c|c|}
\hline \multicolumn{2}{|c|}{$\begin{array}{l}\text { Authors: } \\
\text { Josef J. de Beer }{ }^{1} \\
\text { Ben-Erik van Wyk }{ }^{2}\end{array}$} \\
\hline \multicolumn{2}{|c|}{$\begin{array}{l}\text { Affiliations: } \\
{ }^{1} \text { Department of Science } \\
\text { and Technology Education, } \\
\text { University of Johannesburg, } \\
\text { South Africa }\end{array}$} \\
\hline \multicolumn{2}{|c|}{$\begin{array}{l}{ }^{2} \text { Department of Botany } \\
\text { and Plant Biotechnology, } \\
\text { University of Johannesburg, } \\
\text { South Africa }\end{array}$} \\
\hline \multicolumn{2}{|c|}{$\begin{array}{l}\text { Correspondence to: } \\
\text { Josef de Beer }\end{array}$} \\
\hline \multicolumn{2}{|c|}{$\begin{array}{l}\text { Email: } \\
\text { josefdb@uj.ac.za }\end{array}$} \\
\hline \multicolumn{2}{|c|}{$\begin{array}{l}\text { Postal address: } \\
\text { PO Box 524, Auckland Park } \\
\text { 2006, South Africa }\end{array}$} \\
\hline \multicolumn{2}{|c|}{$\begin{array}{l}\text { Dates: } \\
\text { Received: } 21 \text { Aug. } 2013 \\
\text { Accepted: } 17 \text { Sept. } 2013 \\
\text { Published: } 08 \text { Nov. } 2013\end{array}$} \\
\hline \multicolumn{2}{|c|}{$\begin{array}{l}\text { How to cite this article: } \\
\text { De Beer, J.J. \& Van Wyk, B-E., } \\
2013 \text {, 'Voeding en fisieke } \\
\text { welstand as deel van die } \\
\text { skoolkurrikulum: 'n Interven- } \\
\text { sie in 'n onderwysopleiding- } \\
\text { program', Suid-Afrikaanse } \\
\text { Tydskrif vir Natuurwetenskap } \\
\text { en Tegnologie 32(1), Art. } \\
\text { \#771, } 6 \text { pages. http://dx.doi. } \\
\text { org/10.4102/satnt.v32i1.771 }\end{array}$} \\
\hline \multicolumn{2}{|c|}{$\begin{array}{l}\text { Copyright: } \\
\text { (C) 2013. The Authors. } \\
\text { Licensee: AOSIS } \\
\text { OpenJournals. This work } \\
\text { is licensed under the } \\
\text { Creative Commons } \\
\text { Attribution License. }\end{array}$} \\
\hline \multicolumn{2}{|l|}{ Read online: } \\
\hline 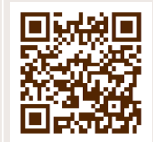 & $\begin{array}{l}\text { Scan this QR } \\
\text { code with your } \\
\text { smart phone or } \\
\text { mobile device } \\
\text { to read online. }\end{array}$ \\
\hline
\end{tabular}

Hierdie artikel beskryf onderwysstudente se deelname aan simulasiespele tydens 'n ekskursie. Daar word gekyk na hoe die Verenigde Nasies se agt millennium-ontwikkelingsdoelwitte betrek kan word in die opleidingskurrikulum vir onderwysers. In die besonder word daar gefokus op aktiwiteite wat gerig is om voornemende onderwysers meer sensitief te maak vir die MIV en VIGS-pandemie en voedselsekuriteit. Die navorsers werk vanuit 'n nieu-Vygotskiaanse vertrekpunt wat bekend staan as aktiwiteitsteorie, waarbinne hulle simulasiespele as die primêre werktuig vir studente se deelname beskou. Die studente neem deel in 'n homo ludensmodus (dié van die spelende mens, volgens Huizinga 1955) as 'n vorm van beliggaamde betekenisgewing. Deur van aktiwiteitsteorie as 'n lens gebruik te maak, word daar voorgestel dat die ekskursiekurrikulum belofte inhou vir die leerproses van studente aangaande sake rakende MIV- en VIGS-opvoeding, armoede en voedselsekuriteit.

Nutrition and physical well-being in the school curriculum: An intervention in a teachers education programme. This article describes education students' engagement in simulation games during an excursion. The focus is on how the United Nations' eight millennium development goals could be addressed in teacher education programmes. The authors specifically look at activities that aim to sensitize teachers about HIV and AIDS and food security. They view learning from a neo-Vygotskian perspective known as activity theory, which rates simulation games as the primary strategy for learner involvement. The students become homo ludens (playing human, Huizinga 1955), and this facilitates embodied meaningmaking. From this position it is suggested that the particular curriculum holds some promise for exploring HIV and AIDS education, poverty and food security.

\section{Inleiding}

Die Verenigde Nasies se agt millennium-ontwikkelingsdoelwitte wat teen 2015 bereik moet word, stel hoë eise aan die onderwys, en aan onderwyseropleiding. Die Suid-Afrikaanse onderwyser werk in 'n milieu waar 5.6 miljoen mense met MIV saamleef, en waar 270000 mense jaarliks aan VIGSverwante siektes sterf (AIDS Foundation 2013). Die VIGS-stigting van Suid-Afrika lys 'n getal faktore wat die verspreiding van VIGS versnel: armoede, marginalisering in die samelewing, hoë vlakke van seksueel oordraagbare infeksies, die lae status van vroue in sommige gemeenskappe, seksuele geweld, en migrasie-arbeid. Die Suid-Afrikaanse onderwyser sit verder met die dilemma dat kinders uit verskillende maatskaplike en ekonomiese omstandighede in dieselfde klas sit, en 'n kind uit 'n goeie middelklashuis dalk langs 'n kind sit wat twee dae laas geëet het. Die vraag is of voornemende onderwysers voldoende toegerus word om hierdie aspekte in hul onderrig te hanteer.

In dié artikel fokus ons op 'n intervensie onder B.Ed.-studente in hul eerste jaar in die Fakulteit Opvoedkunde aan die Universiteit van Johannesburg. Sedert 2007 bied die Fakulteit Opvoedkunde jaarliks 'n ekskursie van vier dae aan (die eerste drie jaar 2007-2009 in die Golden Gate Hooglande Nasionale Park in die Vrystaat, en die afgelope vier jaar sedert 2010 by Achterbergh, in die Wieg van die Mensdom). Die getal studente per kamp word beperk tot 150, en om dié rede is daar jaarliks vier tot vyf sulke kampe. Die oorhoofse fokus van die ekskursie is die professionele ontwikkeling van onderwysstudente as toekomstige onderwysers, en tydens so 'n ekskursie word verskeie van die millennium-ontwikkelingsdoelwitte betrek, soos gesien kan word in Tabel 1. Ons beskou die ekskursie as 'n afsonderlike, maar komplementerende aktiwiteitsisteem wat die formele lesinglokaal op kampus aanvul. Later in die artikel bespreek ons die ekskursie deur gebruik te maak van die kultuurhistoriese aktiwiteitsteorie (Cultural Historical Activity Theory [CHAT]). 
TABEL 1: Aktiwiteite tydens die ekskursie wat op die millenniumontwikkelingsdoelwitte fokus.

\begin{tabular}{|c|c|c|}
\hline Millenniumontwikkelingsdoelwit & Ekskursieaktiwiteit & Bespreking \\
\hline Voedselproduksie, voedselsekuriteit en volhoubaarheid & Die voedselbanketspel & $\begin{array}{l}\text { Dit is 'n kragtige aktiwiteit om onderwysstudente bewus te maak van die } \\
\text { spektrum van leerders (gebaseer op maatskaplike en ekonomiese status) } \\
\text { waarmee hulle in die klaskamer gaan werk. }\end{array}$ \\
\hline \multirow[t]{2}{*}{ Die bestryding van MIV en VIGS } & Die MIV en VIGS-rolspel & $\begin{array}{l}\text { 'n Aktiwiteit wat beklemtoon hoe groot die risiko is om MIV en VIGS op te tel } \\
\text { tydens onveilige seks. }\end{array}$ \\
\hline & Die bosdialoog & $\begin{array}{l}\text { Maatskaplike faktore wat 'n uitwerking het op gesondheidsorg (bv. die status } \\
\text { van vroue) word in hierdie aktiwiteit belig. }\end{array}$ \\
\hline $\begin{array}{l}\text { Voeding, voedsel en fisieke welstand as deel van die } \\
\text { skoolkurrikulum }\end{array}$ & $\begin{array}{l}\text { Ontwikkeling van 'n lesplan om die } \\
\text { millenniumontwikkeling- } \\
\text { doelwitte te betrek }\end{array}$ & $\begin{array}{l}\text { Onderwysstudente (in verskillende spesialiserings-rigtings) moet aandui hoe } \\
\text { hulle die ontwikkeling-doelwitte in verskillende vakke sal nastreef. }\end{array}$ \\
\hline
\end{tabular}

\section{Metodologie}

Met die uitsondering van die bosdialoë, wat vir die eerste keer in 2013 geïmplimenteer is, is data ingesamel onder 3500 studente wat die afgelope sewe jaar aan die ekskursies deelgeneem het. Data is ingesamel deur fokusgroeponderhoude, vraelyste, waarneming (direkte waarneming, terwyl van die aktiwiteite ook opgeneem is op video wat dan later geanaliseer is), en deur middel van die studente se portefeuljes wat ná die ekskursie vir assessering ingedien word. In die geval van die bosdialoë is daar ook na Facebook- besprekings gekyk, wat die maand ná die ekskursie plaasgevind het. Die navorsing is kwalitatief, en ons het kodes, kategorieë en temas geïdentifiseer. Kwalitatiewe inhoudsanalise is gedoen (Miles \& Huberman 2004). (Videomateriaal is ontleed deur van Transana-sagteware gebruik te maak.) Alle studente het toestemmingsbriewe onderteken, nadat die navorsing aan hulle verduidelik is, om hulle vrywillige deelname te verklaar. Die studente wie se foto's in hierdie artikel gebruik is, het skriftelike toestemming daarvoor verleen.

\section{Die kurrikulum: 'n Paar voorbeelde van die millenniumontwikkelingsdoelwitaktiwiteite}

Voorts gaan daar gekyk word na vier van die leeraktiwiteite tydens die ekskursie:

- Die voedselbanketspel en maatskaplike geregtigheid in die klaskamer

- Die MIV- en VIGS-rolspel

- Die bosdialoog

- Lesplannewatop diemillennium-ontwikkelingsdoelwitte fokus

In die gedeelte hierna sal ons dié aktiwiteite belig, en ook data voorhou oor student se belewenis hiervan.

\section{Die voedselbanketspel en maatskaplike geregtigheid in die klaskamer}

Elke student ontvang 'n paspoort. 'n Paar gelukkige studente ontvang 'n paspoort vir 'n geïndustrialiseerde land soos die VSA, Finland, Japan of Frankryk. Nog 'n paar studente ontvang paspoorte vir die BRICS lande (Brasilië, Rusland, Indië, China of Suid-Afrika). Die oorgrote meerderheid van die studente ontvang egter paspoorte van ontwikkelende lande (bv. die Demokratiese Republiek van die Kongo, Liberië, Mali, Mosambiek of Ethiopië). In Figuur 1 kan van die studente met hul onderskeie paspoorte gesien word. Afhangende van die land van 'herkoms' (paspoort) ontvang elke student fondse waarmee hulle voedsel by die bankettafel kan koop. Die bedrae word bereken volgens die data in Tabel 1, wat die menslike-ontwikkelingsindeks (Human Development Index) en brutobinnelandse produk (BBP) van verskeie lande aandui (Human Development Report 2013). Byvoorbeeld, 'n persoon met 'n Noorweegse paspoort ontvang US\$100, iemand van Brasilië US\$8, 'n Suid-Afrikaner US\$6, 'n Nigeriër US\$1, en iemand van die Demokratiese Republiek van die Kongo ontvang geen geld nie. Studente kan dan voedsel van die bankettafel koop (en geniet). Uiteraard kan sommige studente na hartelus koop, terwyl ander studente nie in staat is om enigiets te koop nie. Die studente vergelyk ook die lewensverwagting, geboortekoers en MIV- en VIGSinfeksiekoerse van die onderskeie lande.

Nadat die studente die geleentheid gekry het om voedsel te koop volg daar ' $n$ bespreking. Wat is die implikasies van hierdie maatskaplike en ekonomiese skeiding vir die onderwyser in die klaskamer? Hoe hanteer die onderwyser' $n$ situasie waarin sommige leerders uit gegoede huise kom waar kinders altyd voedsel op die tafel het, en selfs die geleentheid het om oorsee te reis, terwyl daar in dieselfde klas kinders is wat onder die broodlyn leef? Studente word dan gevra om voorbeelde te gee van hoe hulle bogenoemde statistiek sal hanteer in die vakke wat hulle aanbied. In die senior fase in die natuurwetenskappe en die Lewenswetenskappekurrikulum vir Verdere Onderwys en Opleiding sal op aspekte gefokus word soos hoe mense in ontwikkelende lande aangemoedig kan word om geboortebeperking toe te pas, en hoe werklose mense deur onderwys gehelp kan word om 'n bestaan te voer.

\section{Die MIV- en VIGS-rolspel}

Baie mense in Suid-Afrika word so gebombardeer met die ABC van VIGS-voorkoming ('abstain, be faithful, condomise', [weerhouding van seks, getrouheid aan 'n enkele seksmaat, en die gebruik van kondome]) dat hulle nie meer ag slaan op die VIGS-boodskap nie. Ons ervaring is dat die VIGS-rolspel wat hier bespreek word, kragtig genoeg is om studente opnuut bewus te maak van die VIGS-pandemie in ons land. Elke student ontvang twee deursigtige plastiekglasies, wat een derde van die volume gevul is met ' $n$ vloeistof (Petersen, De Beer \& Dunbar-Krige 2011). Die oorgrote meerderheid van die studente $(83 \%)$ ontvang glasies met ' $n$ verdunde kalsiumkarbonaat oplossing. (Water is ewe effektief, maar die kalsiumkarbonaat verleen ' $n$ melkerige kleur, wat ' $n$ beter voorstelling in die simulasiespel bied van 'n liggaamsvloeistof soos semen). Een van die glasies is die kontrole vir (MIVen VIGS-status aan die begin van die spel), en die tweede 
TABEL 2: Data vir die Banketspel.

\begin{tabular}{|c|c|c|c|c|c|c|c|}
\hline Land & $\begin{array}{l}\text { Rangorde in terme } \\
\text { van die menslike } \\
\text { ontwikkeling indeks } \\
\text { (MOI) }\end{array}$ & $\begin{array}{l}\text { MOI (Human } \\
\text { development index) } \\
\text { (HDI) }\end{array}$ & Lewensverwagting & $\begin{array}{l}\text { MIV- en VIGS- } \\
\text { infeksie }\end{array}$ & $\begin{array}{l}\text { Geboortesyfer } \\
\text { (babas gebore } \\
\text { per vrou) }\end{array}$ & $\begin{array}{l}\text { Babasterftekoers } \\
\text { (sterftes per } 1000 \\
\text { geboortes) }\end{array}$ & $\begin{array}{l}\text { BBP (bruto } \\
\text { binnelandse produk) } \\
\text { (GDP) (US\$) }\end{array}$ \\
\hline Ysland & 1 & 0.968 & 80.4 & 0.20 & 1.99 & 2.9 & 55462 \\
\hline Noorweë & 2 & 0.968 & 79.7 & 0.10 & 1.80 & 3.3 & 95062 \\
\hline Kanada & 3 & 0.967 & 80.3 & 0.30 & 1.50 & 4.8 & 45428 \\
\hline Australië & 4 & 0.965 & 80.6 & 0.10 & 1.70 & 4.4 & 47400 \\
\hline lerland & 5 & 0.960 & 77.9 & 0.10 & 1.97 & 4.9 & 61810 \\
\hline Japan & 8 & 0.956 & 81.0 & 0.10 & 1.30 & 3.2 & 38559 \\
\hline Frankryk & 11 & 0.955 & 80.8 & 0.40 & 1.88 & 4.2 & 46016 \\
\hline Finland & 12 & 0.954 & 78.6 & 0.10 & 1.75 & 3.7 & 51989 \\
\hline VSA & 15 & 0.950 & 78.0 & 0.60 & 2.04 & 6.3 & 46859 \\
\hline Spanje & 16 & 0.949 & 79.7 & 0.70 & 1.29 & 4.2 & 35331 \\
\hline Italië & 19 & 0.945 & 79.9 & 0.50 & 1.20 & 5.0 & 38996 \\
\hline Verenigde Koninkryk & 21 & 0.942 & 78.7 & 0.20 & 1.60 & 4.8 & 43785 \\
\hline Kuba & 48 & 0.855 & 75.0 & 0.10 & 1.63 & 5.1 & 4830 \\
\hline Meksiko & 51 & 0.842 & 75.8 & 0.30 & 2.40 & 16.7 & 10235 \\
\hline Brasilië & 70 & 0.807 & 72.7 & 0.40 & 2.35 & 23.6 & 8197 \\
\hline Suid-Afrika & 125 & 0.670 & 42.4 & 10.10 & 2.80 & 44.8 & 5693 \\
\hline Indië & 132 & 0.609 & 68.5 & 0.30 & 3.11 & 55.0 & 1016 \\
\hline Nigerië & 154 & 0.499 & 47.4 & 3.10 & 5.85 & 109.5 & 1451 \\
\hline Ethiopië & 169 & 0.389 & 49.2 & 2.00 & 6.10 & 116.0 & 324 \\
\hline Mosambiek & 175 & 0.366 & 40.9 & 12.05 & 5.52 & 95.9 & 465 \\
\hline Liberië & 176 & 0.364 & 40.3 & 5.10 & 6.80 & 70.3 & 212 \\
\hline $\begin{array}{l}\text { Demokratiese } \\
\text { Republiek van die } \\
\text { Kongo }\end{array}$ & 177 & 0.361 & 53.2 & 4.09 & 6.30 & 113.5 & 184 \\
\hline Sierra Leone & 179 & 0.329 & 38.0 & 7.0 & 6.50 & 160.0 & 332 \\
\hline
\end{tabular}

Nota: Vind asb. die volledige gebaseerde bronne in die literatuurverwysings van hierdie artikel, De Beer, J.J. \& Van Wyk, B-E., 2013, 'Voeding en fisieke welstand as deel van die skoolkurrikulum: ' $n$ Intervensie in 'n onder wysopleidingprogram', SA Tydskrif vir Natuurwetenskap en Tegnologie 32(1), Art. \#771, 6 pages. http://dx.doi.org/10.4102/satnt.v32i1.771, vir meer inligting.
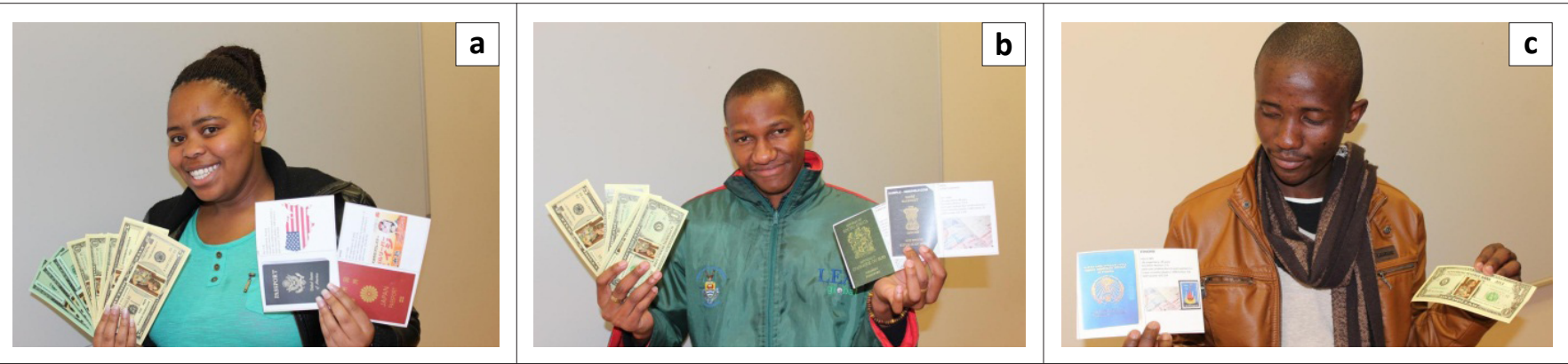

FIGUUR 1: Studente ontvang geld, gebaseer op hul paspoorte, (a) geïndustrialiseerde (ontwikkelde) land, (b) BRICS-land (opkomende ekonomie) en (c) ontwikkelende land.

glasie (die eksperiment) dui die MIV- en VIGS-status aan die einde van die rolspel aan. Dié $83 \%$ van die studente is MIV-negatief. Die ander $17 \%$ van die studente ontvang twee glasies met natriumhidroksied ('n sterk chemiese basis), en hulle verteenwoordig die deel van die SuidAfrikaanse bevolking wat MIV-positief is (Hierdie syfers is gebaseer op die statistiek wat verskaf word deur die VIGSstigting van Suid-Afrika). Ons voeg ook kalsiumkarbonaat by die natriumhidroksied-oplossing sodat die kleur van die vloeistowwe eenders is. Studente moet dan een van die glasies neem (die proef), en vyf uitruilings doen met verskillende mense. (Studente sal hul glasie se inhoud voeg by die glasie van een ander persoon, dit meng, en die helfte van die vloeistof teruggooi in die eerste persoon se glasie. Dit verteenwoordig een uitruiling). Ná vyf sulke uitruilings (wat onbeskermde seks voorstel), word beide glasies van elke student met fenolftaleïen getoets. Fenolftaleïen is 'n chemiese indikator, en in die teenwoordigheid van 'n basisoplossing sal die fenolftaleïen ' $n$ diep pienk kleur verleen. Dit is ' $n$ aanduiding van MIV-positiewe status (Petersen et al. 2012). Waar slegs $17 \%$ van die studente voor die rolspel MIVpositief was, is meer as $90 \%$ van die klas aan die einde van die rolspel met die virus besmet. Voor die rolspel begin, identifiseer ons twee studente om die rol te speel van 'n seksuele roofdier (sexual predator). Hierdie twee studente is die enigste studente wat vooraf ingelig word aangaande die rolspel, en hulle word gevra om vloeistowwe uit te ruil met soveel studente as moontlik. Na afloop van die rolspel, volg 'n bespreking. Later in die artikel bespreek ons kortliks die bevindings.

\section{Die bosdialoog}

In 2013 het ons 'n nuwe aktiwiteit ingesluit in die program, naamlik 'n bosdialoog (bush dialogue). Inklusiewe onderrig vereis van die onderwyser om sensitiwiteit te openbaar teenoor 
verskillende kulture, en om respek en verdraagsaamheid by kinders te kweek vir ander godsdienste, mense met ander seksuele voorkeure, geslagsgelykheid, ensovoorts. Die bosdialoogaktiwiteit (geskeduleer as aandaktiwiteit) begin met 'n gesamentlike bespreking oor bogenoemde aspekte, en daarna word daar in kleiner groepe hieroor om kampvure gesels. Ná die kamp word die gesprekke voortgesit deur middel van sosiale media soos Facebook. Soos vroeër genoem, is die VIGS-stigting van mening dat faktore soos vroueregte wat nie eerbiedig word nie, een van die redes vir die groot VIGS-pandemie is.

\section{Lesplanne wat op die millennium- ontwikkelingsdoelwitte fokus}

Ná die ekskursie word daar van die studente verwag om 'n portefeulje in te dien, waarin hulle onder andere lesplanne insluit wat op die millennium-ontwikkelingsdoelwitte fokus. Studente moet die Kurrikulum- en Assesseringbeleidsverklaring (KABV) vir hul vakke bestudeer, en temas identifiseer wat aansluit by die millennium-ontwikkelingsdoelwitte. Voorbeelde in die natuurwetenskappe en lewenswetenskappe sluit in onderwerpe soos die rol van inheemse flora in voedsel-sekuriteit, waarom uitheemse plante (soos die patat) waarskynlik 'n beter oplossing bied as 'n volhoubare voedselbron, en die uiteindelike gevolgtrekking dat stedelike, asook kleinskaalse landbou min of geen impak maak op voedselsekuriteit nie, en dat die opheffing van armoede die enigste praktiese benadering is om voedselsekuriteit te verseker. Die staat kan sekerlik ook 'n rol speel om die prys van stapelvoedsel te subsideer, soos wat in eerstewêreldlande gebeur. MIV en VIGS word ook beklemtoon in die KABV, en baie studente ontwikkel lesplanne om hierdie saak te betrek deur van 'n meer innoverende pedagogie gebruik te maak.

\section{'n Oorsig van die ekskursie: Deur'n lens van die kultuurhistoriese aktiwiteitsteorie}

Die navorsers werk vanuit 'n nieu-Vygotskiaanse vertrekpunt wat bekend staan as aktiwiteitsteorie, waarbinne hulle simulasiespele as die primêre werktuig vir studente se deelname beskou (De Beer \& Henning 2011). Sitte en Wohlschlagal (2001) is van mening dat simulasiespele komplekse sake of prosesse leefbaar (erlebbar) en toeganklik maak, en menslike ervaring en emosie in die proses ontsluit. Die studente neem deel in 'n homo ludens-modus (dié van die spelende mens, Huizinga 1955) as 'n vorm van beliggaamde betekenisgewing ('embodied meaning-making'). Ragpot (in $d r u k$ ) wys daarop dat drama en simulasie as pedagogie in die tersiêre sektor verwaarloos word, ondanks die leerpotensiaal wat dit inhou. Die deelnemende studente leer aangaande die millenniumdoelwitte deur wat Veresov (2007), 'n Russiese navorser en hedendaagse vertaler van Lev Vygotsky se werk, dramatiese botsings (dramatical collisions) noem. Tydens die rolspel ontwikkel daar spanning. Studente het byvoorbeeld verskillende sienings aangaande geslagsgelykheid, dikwels ingekleur deur godsdienstige beskouings. Sommige van die manstudente (baie interessant is dat dit veral die Zoeloestudente blyk te wees) voel dat Eva deur God uit Adam se rib geskape is, en daarom 'n dienende Marta behoort te wees. Sommige van die manstudente glo ook dat poligamie heeltemal geregverdig is. Die volgende dialoog tussen twee studente en die fasiliteerder van die bosdialoog (meneer Khomotso Ntuli ${ }^{1}$ ) is 'n goeie voorbeeld van Veresov se 'dramatiese botsings':

Manlike student: 'As my vrou my nie 'n seun kan baar nie, is dit binne my reg om ' $n$ ander vrou te kry wat vir my 'n seun kan gee².'

Vroulike student: 'So wat jy sê, is dat 'n seun meer wenslik is as 'n dogter?'

Fasiliteerder: 'Ek wil terugkeer na die vorige standpunt. Meneer, en sê nou dat $u$ steriel is? Kan $u$ vrou dan gemeenskap hê met 'n ander man sodat sy 'n kind kan kry?'

Manlike student: 'Definitief nie!' (Student is baie heftig.) 'Ek soek nie 'n vrou met losse sedes nie.'

Dit is belangrik om hierdie gesprekke te voer in onderwysopleidingsprogramme - die studente is môre se onderwysers. Soos reeds genoem, wys die VIGS-stigting van Suid-Afrika daarop dat bogenoemde standpunte oor geslagsgelykheid die MIV- en VIGS-pandemie verder aanvuur. Vanuit'n kultuurhistoriese aktiwiteitsteorie (CHAT soos dit in die literatuur bekend staan) is die navorsers van mening dat die spanning wat tydens die ekskursie geskep word, die katalis is vir verdere dialoog, wat hopelik kan lei tot veranderde sienings en praktyke. Aktiwiteitsteorie is ' $n$ lens om te kyk na die onderrig-leergebeure, en hoe die subjek (die student) omgaan met die instrumente (tools), reëls (van beide die samelewing, en die ekskursie), en die gemeenskap (bv. die dosent en medestudente), in hul leerproses om die objek van die aktiwiteit te bereik (in hierdie geval, 'n bewustheid van die millennium-ontwikkelingsdoelwitte). Derdegenerasiekultuurhistoriese aktiwiteitsteorie (KHAT) is verfyn deur Yrjö Engeström $(1987,2001)$. KHAT belig spanning tussen bogenoemde komponente, byvoorbeeld konflik tussen studente wat verskillende opinies huldig, of spanning wat 'n bepaalde pedagogiese benadering teweegbring (die instrument). Deur KHAT as lens te gebruik beskou ons tydens die ekskursie die rolspelaktiwiteite as 'n aktiwiteitsisteem met sy eie dinamiek, en kyk hoe die kurrikulum effektief op die aspekte van die millenniumdoelwitte kan fokus. Binne die sone van proksimale ontwikkeling ('zone of proximal development' van Vygotsky 1978) kan rolspel effektief wees en steiers (scaffolding) deur middel van hierdie 'dramatiese botsings' bou vir studente se leer en professionele ontwikkeling. Ons is van mening dat die spanning die sone van proksimale ontwikkeling tot sy uiterste grense verskuif. Veresov en Vygotsky se werk word gekenmerk deur die feit dat hulle Russiese teater as metafoor gebruik. Ons sien op 'n soortgelyke wyse die spanning wat geskep word binne-in hierdie sone van proksimale ontwikkeling as 'n metaforiese verhoog, waar die rolspel deur die studente hulle meer bewus maak van die millenniumdoelwitte. Hierdie ekskursie komplementeer die formele lesinglokaal, wat as 'n afsonderlike aktiwiteitsisteem beskou word.

1.Meneer Khomotso Ntuli is deur die universiteit gekontrakteer om die bosdialoe te fasiliteer. Hy werk met jongmense en voer bush dialogues deur van die sosiale media gebruik te maak.

2.Vryelik vertaal. 


\section{Resultate}

Die volgende is ' $n$ paar hooftemas wat geïdentifiseer is.

\section{Die pedagogie van spel is effektief om studente bewus te maak van die ontwikkelingsdoelwitte}

Aktiwiteite soos die VIGS-simulasiespel en die voedselbanketspel, spreek tot die affektiewe domein, en blyk baie effektief te wees om studente se bewustheid van en kennis aangaande die millenniumdoelwitte te verbreed. Die volgende opmerkings van studente dien as illustrasie:

- Een van die studente se terugvoer ${ }^{3}$ op die MIV- en VIGSsimulasiespel wys watter impak dit het:

- 'Ek het nog altyd enige MIV- en VIGS-lesse afgelag, 'n grap daarvan gemaak en my maats geamuseer. Ek is seksueel aktief, en het gewoonlik meer as een meisie. Hierdie aktiwiteit was anders. Dit was soos 'n vuishou in die maag ... en ek het baie bang geword. Ek loop so 'n hoë risiko. Ek moet myself laat toets. En ek moet ophou met my rondslapery.'

- 'n Ander student se terugvoer op die VIGS rolspel was:

- 'Voor die VIGS-speletjie het ek my onderwysfilosofie (pledge) geskryf, en hoe ek lig vir mense wil bring. Ek het nie vir 'n oomblik aan my eie seksuele gedrag gedink nie, en dat ek met verskeie mense slaap nie. Dalk bring ek nie lig in mense se lewens nie, maar hartseer en pyn. Die VIGS-speletjie het my laat besef dat my filosofie (pledge) meer as net woorde moet wees. I need to walk the talk. [Ek moet die daad by die woord voeg.] Ek moet getrou wees aan een persoon, en moet veilige seks beoefen. Verandering moet by my begin.'

- Die voedselbanketspel het soortgelyke opmerkings uitgelok:

- 'Dit is so onregverdig. Ek het 'n paspoort vir Mosambiek gehad, en kon niks by die winkel koop nie, terwyl een van my vriende, wat 'n paspoort vir die Verenigde State van Amerika gehad het, na hartelus kon koop.'

- Die studente het ook besef dat dit implikasies het in die klaskamer:

- 'Ek kom uit 'n middelklashuis, waar daar altyd kos op die tafel is. Die aktiwiteit vandag het my laat besef dat ek kinders in my klas gaan hê wat honger ly. Tydens die groepsbespreking, was ek geskok om te hoor dat daar van my studentemaats is wat soms moet klaarkom met een maaltyd ' $n$ dag'.

\section{Die fundamentalistiese beskouings van onderwysstudente moet uitgedaag word}

Om inklusiewe onderwysers te word vra van onderwysopleidingsprogramme om studente krities te laat reflekteer oor hul beskouings aangaande godsdiens, kultuur, geslag en seksuele oriëntering. Tydens die bosdialoë het dit duidelik geword dat baie studente se sienings rondom geslaggelykheid uitgedaag moet word. Soos vroeër genoem, huldig sommige manstudente die siening dat vroue onderdanig aan hul mans moet wees, en in die meeste gevalle word godsdienstige beskouings as rede aangevoer.

3.Vryelik vertaal
Sulke sienings vuur die MIV- en VIGS-pandemie verder aan. Met KHAT as 'n navorsingslens, voer ons aan dat die spanning wat ontstaan tydens die bosdialoë, of tydens die voedselbanketspel, waar studente gekonfronteer word deur armoede, 'n katalis kan wees om studente te laat nadink oor aspekte soos geslagsgelykheid of hongersnood.

\section{Sosiale media kan effektief gebruik word om studente se begrip van die millenniumontwikkelingsdoelwitte te ontwikkel}

Ná die ekskursie, is die gesprekke wat begin is tydens die bosdialoë voorgesit deur van die sosiale media gebruik te maak. Gesprekke van studente op Facebook is geanaliseer, en wat interessant was, is dat studente meer genuanseerde standpunte gehuldig het op Facebook, vergeleke met die aanvanklike besprekings om die kampvure. Oor die algemeen was studente op Facebook minder uitgesproke en veroordelend gewees oor sake soos homoseksualiteit. Een van die studente het selfs verklaar dat hy gay is, en dat dit vir hom baie bevrydend is dat hy nie meer met hierdie geheim hoef saam te leef nie. Vanuit 'n Vygotskiaanse perspektief maak dit sin. Veresov (2004) wys daarop dat Vygotsky se werk dikwels Russiese teater as metafoor gebruik. Die gebeure tydens die kamp, waar studente inhoud deur sosiale interaksie verken, kan beskou word as die eerste vlak van leer (die verhoog). Ná die kamp vind daar egter internalisering plaas. Terwyl studente reflekteer en aan hul portefeuljes werk, kom baie van hulle tot 'n meer genuanseerde begrip - die tweede vlak waarvan Veresov praat (in teatertaal, wat agter die skerms gebeur). Hierdie meer genuanseerde standpunte wat op Facebook as platform gekommunikeer is, dui daarop dat daar dikwels ' $n$ inkubasieperiode nodig is vir internalisering om plaas te vind.

Wat verder interessant is, is dat studente meer holistiese sienings ontwikkel, en besef hoe baie van hierdie sake met mekaar verband hou. So byvoorbeeld word die rol van voeding in die bevegting van MIV en VIGS ingesien, en dat 'n gebalanseerde dieet onontbeerlik is vir VIGS-lyers om die verswakte imuunstelsel te help opbou.

\section{Gevolgtrekking}

Die navorsing aangaande die rol van die ekskursie vir onderwysstudente in hul eerste jaar oor die afgelope sewe jaar dui aan dat die rolspel tydens die ekskursie 'n baie effektiewe pedagogie is, en waarskynlik meer effektief is as die tradisionele lesing (De Beer \& Henning 2011; Petersen et al. 2011). Tydens hierdie rolspel kry studente ' $n$ byna viserale belewenis van aspekte van die millenniumdoelwitte soos voedselsekuriteit en die bekamping van MIV en VIGS. Op die Vygotskiaanse verhoog, met sy dramatiese botsings (Veresov 2007 se 'dramatical collisions' [dramatiese botsings]) word studente gekonfronteer met alternatiewe sienings, en word daar van studente verwag om krities na hul eie wêreldbeskouing en waardes te kyk. Hopelik vind van hierdie aktiwiteite en insigte ook hul weg na die klaskamer. So 'n ekskursie, waar die studente betrokke raak in 'n homo ludens-modus (spelende mens) dra hopelik by om van die 
studente meer inklusiewe onderwysers te maak, wat aktiewe agente sal wees om na die millenniumdoelwitte te streef.

\section{Erkenning}

Ons bedank die UJ studente van die afgelope sewe jaar vir hule entoesiastiese deelname aan die program en die navorsing, en vir die samewerking van mede-navorsers Elbie Henning, Nadine Petersen, Helen Dunbar-Krige en Khomotso Ntuli.

\section{Outeursbydrae}

J.d.B. (Universiteit van Johannesburg) was die koördineerder van die ekskursie, en samesteller van die kurrikulum en verantwoordelik vir die ontleding van data en hoofskrywer van die artikel. B-E.v.W. (Universiteit van Johannesburg) was raadgewend betreffende die rol van flora om hongersnood te bekamp.

\section{Mededingende belange}

Die outeurs verklaar hiermee dat hulle geen finansiële of persoonlike verbintenis het met enige party wat hulle nadelig kon beïnvloed in die skryf van hierdie artikel.

\section{Literatuurverwysings}

AIDS Foundation South Africa, 2013, AIDS Foundation of South Africa, viewed 16 September 2013, from http://www.aids.org.za
Central Intelligence Agency, 2013, The World Factbook, viewed 16 September 2013, from https://www.cia.gov/library/publication/the-world-factbook/

De Beer, J. \& Henning, E., 2011, 'Retreating tot a Vygotskian stage where pre-service teachers play out social "dramatical collisions"', Acta Academica 43(4), 1-26.

Engeström, Y., 1987, 'Learning by expanding: An activity-theoretical approach to developmental research', Unpublished PhD dissertation, San Diego, University of California.

Engeström, Y., 2001, 'Expansive learning at work: Toward an activity theoretical reconceptualization', Journal of Education and Work 14(1), 133-156.

Huizinga, J., 1955, Homo ludens: A study of the play element in culture, The Beacon Press, Boston

Human Development Report, 2013, 'Report of the United Nations Development Project (1990-2013)', viewed 16 September 2013, from http://hdr.undp.org/en/ reports/global/hdr1990/chapters/

International Monetory Fund, 2008, World Economic Outlook, viewed 16 September 2013, from http://www.imf.org/external/pubs/ft/weo/2008/01

Miles, M.B. \& Huberman, A.M., 2004, Qualitative data analysis: An expanded sourcebook, Sage, London.

Petersen, N., De Beer, J.J. \& Dunbar-Krige, H., 2011, 'What does it help to take precautions - we will get AIDS anyway: Using a simulation game for HIV and AIDS education with pre-service teachers', African Journal of AIDS research 10(1), 7381. http://dx.doi.org/10.2989/16085906.2011.575550

Ragpot, L., in druk, 'Performing plays on theories of cognitive development in preservice teacher education', South African Journal of Childhood Education.

Reader's Digest, 2004, Reader's Digest World Atlas, Readers Digest Association, Lodon.

Sitte, W. \& Wohlschlagl, H., 2001, 'Didactic plays: Contributions for the teaching of geography and industrial studies instruction' (Beitrage zur Didaktik des Geographie und Witschaftskunde Unterricht, Vienna), Institute for Geography and Regional Studies, University of Vienna.

Veresov, N., 2004, 'Zone of proximal development (ZPD): The hidden dimension?', in A. Ostern \& R. Heila-Ylikallio (eds.), Sprak som kultur - brytningar I tid och rum, vol. 1, pp. 13-30, Abo Akademi, Vasa, Finland.

Veresov, N., 2007, 'Sign mediation: Sagic triangle: Sign-mediated action and behind', Fourth Nordic Conference on Cultural and Activity Research, 15-17 June 2007, Oslo, Norway.

Vygotsky, L.S., 1978, Mind in Society: The development of higher psychological processes, ed. and transl. M. Cole, J. Steiner, S. Scribner \& E. Souberman, Cambridge, MA, Harvard University Press. 